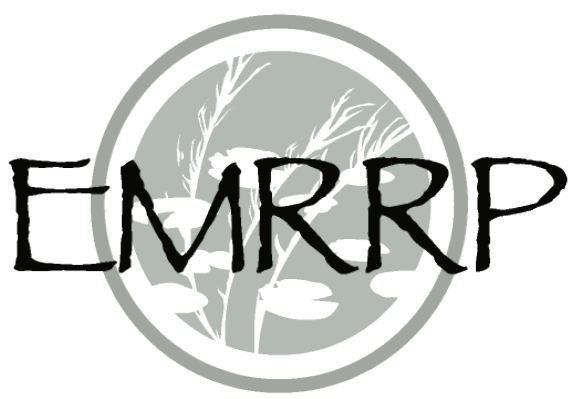

\title{
Developing Best Management Practices for Coastal Engineering Projects that Benefit Atlantic Coast Shoreline-dependent Species
}

\author{
by Michael P. Guilfoyle, Jacob F. Jung, Richard A. Fischer
} and Dena D. Dickerson

PURPOSE: This Technical Note (TN) was developed by the U.S. Army Engineer Research and Development Center-Environmental Laboratory (ERDC-EL), to summarize known impacts on seasonal habitats used by migratory shoreline-dependent birds (primarily shorebirds and seabirds) and nesting sea turtles along the Atlantic Coast by U.S. Army Corps of Engineers (USACE) coastal engineering activities. The USACE is responsible for maintaining coastal infrastructure including ports, harbors, shoreline stabilization, and maintenance of the Intracoastal Waterway System (ICWW) along the Atlantic Coast. This infrastructure is essential to the long-term sustainability of national and economic prosperity by ensuring navigation through ports and harbors that transport goods necessary for national and international commerce. Coastal shoreline stabilization and sediment management can also provide opportunities for reductions in storm surge, flood control, residential growth, recreational activities, coastal habitat restoration, and fisheries management. Routine engineering actions by the USACE includes maintenance dredging and dredged material deposition, beach nourishment, inlet realignment and shoreline stabilization, and dike, sea wall, terminal groin and revetment construction. These actions can alter the shape, structure and function of coastal habitats, and have the potential for both positive and negative seasonal effects on shoreline-dependent organisms. The objectives of this technical note include the following: (1) introducing issues concerning coastal engineering impacts on shorelinedependent birds and sea turtles, (2) providing suggestions on specific management approaches that can be used to minimize these impacts, and (3) developing insights for future research and monitoring that should be undertaken to ensure that management actions are having the desired effect on target populations.

BACKGROUND: The U.S. Atlantic coast supports more than 35 shorebird species and an additional 13 tern and skimmer species (Sibley 2016). Five species of sea turtles are known to nest on beaches along the U.S. Atlantic or Gulf Coasts. Many North American birds and sea turtles are highly dependent upon coastal, sediment-based habitats, including beaches, inlets, marshes, bays, and estuaries. Maintenance and enhancement of navigation infrastructure often requires large expenditures in equipment, and the design and implementation of engineering projects to build, maintain, or enhance existing coastal infrastructure. Harbors, ports, approach channels, and the ICWW require sufficient depths to permit navigation of large oceanic cargo vessels used for the 
transport of goods to desired destinations. Subsequently, maintenance dredging moves hundreds of millions of cubic yards of sediment each year. Strategic placement of dredged material can be used to restore eroded beaches (Figure 1), restore wetland or mudflat habitats, be deposited on off-shore islands, or be deposited at sea. Such beneficial use of dredged material is an essential element in the USACE Regional Sediment Management (RSM) (http://rsm.usace.army.mil/) and Engineering With Nature ${ }^{\circledR}(\mathrm{EWN})$ (https://ewn.el.erdc.dren.mil/) programs. A small proportion of dredged material, mostly from urban and industrial regions, may be sufficiently contaminated to require deposition in a confined disposal facility (CDF) or other disposal mechanism to reduce environmental and human exposure.

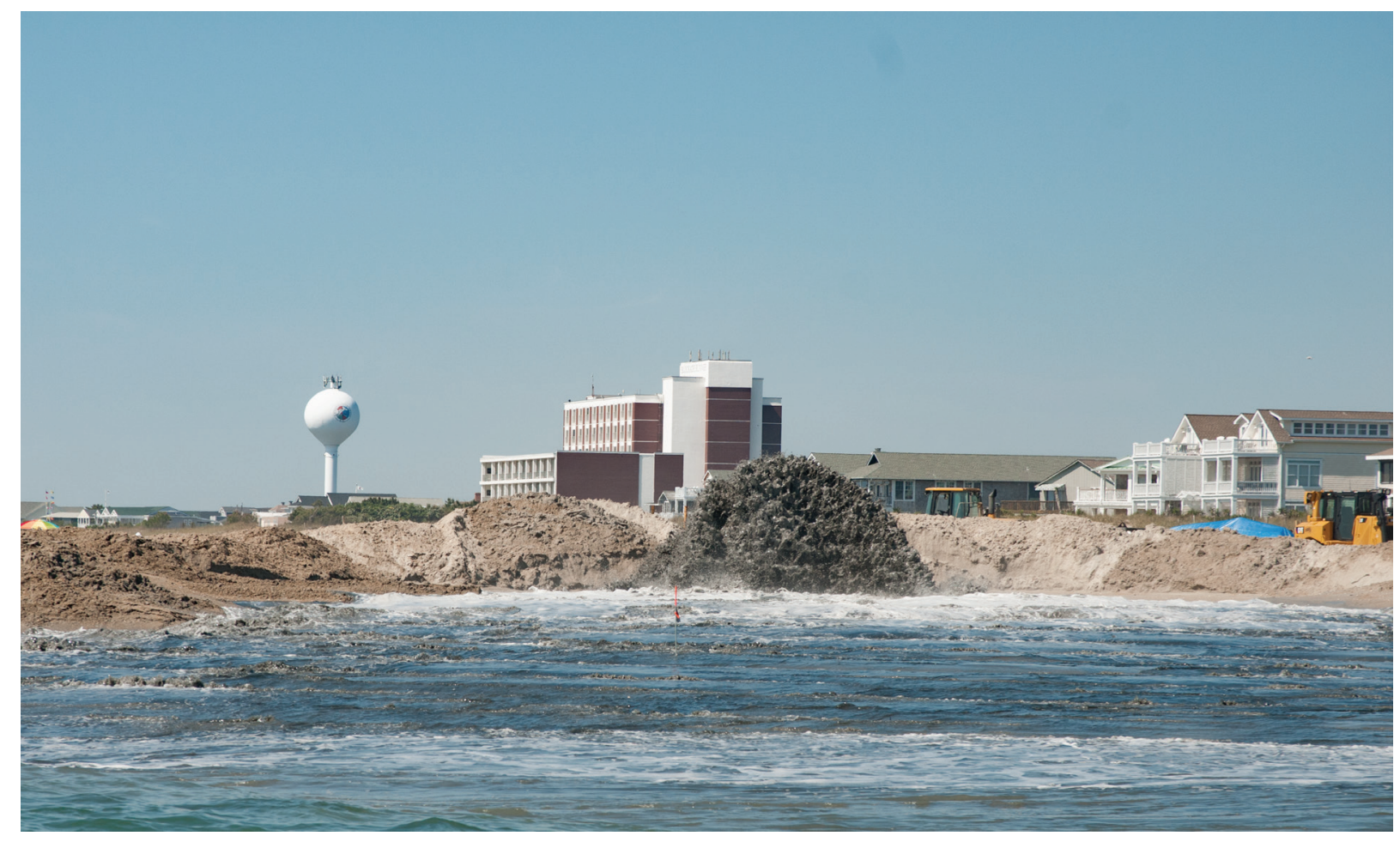

Figure 1. Coastal engineering operations may alter seasonal habitats for shoreline-dependent birds and nesting sea turtles by disturbing habitats during critical nesting, migratory or wintering periods, altering the size and shape of available habitats, and burying or reducing benthic organisms used as prey. (Photo Credit: Walker Golder, National Audubon Society, NC Field Office).

Other engineering projects entail stabilization efforts to minimize erosional processes that endanger human residential and commercial areas. Stabilization, coastal armoring, and sediment management structures include sea walls, jetties, dykes, revetments, and terminal groins. These structures are designed to minimize damage from erosion and storm surge during hurricanes and major storms. These engineered structures can modify ocean current and wave action, and also reduce the meandering nature of estuarine, inlet, and coastal currents and may direct sediment disposition away from navigation channels. The combination of deep navigation channels and stabilization structures can erode existing coastal habitats, and reduce or eliminate formation of natural sand spits, beaches, wetlands, marshes, inlets, and islands that are used by shorelinedependent birds and nesting sea turtles. Inlets are important seasonally for foraging shorebirds, particularly during migration, but these features are often the first areas to receive sediment 
deposition as a means of shoreline stabilization, or are areas where sediments are mined for other coastal projects (Harrington 2008). Deposition of dredged material can temporarily lower site quality for invertebrate populations important in the diets of many migratory shorebirds. The growing human populations along the coast, plus sea level rise and storm intensity due to climate instability, increases the need, rate, and extent of coastal engineering and shoreline stabilization activities, and hastens the potential for large-scale degradation of coastal habitats for shorelinedependent organisms.

Many shoreline-dependent species along the Atlantic Coast are experiencing significant population declines. While conservation efforts to protect and enhance rare or endangered sea turtles along the Atlantic Coast are having a positive impact (Mazaris et al. 2017), beach nourishment and residential growth along coastal areas continue to negatively impact nesting sea turtles (Dickerson et al. 2006). In addition, some Atlantic Coast shorebird populations have declined by $70 \%$ or more. The rapid decline of the rufa subspecies of Red Knot (Calidris canutus rufa) resulted in the listing of this species in 2014 by the U.S. Fish and Wildlife Service as threatened under the Endangered Species Act (ESA) (Figure 2). Further declines in other sensitive shorebird and seabird populations could result in the future listing of the Semipalmated Sandpiper (Calidris pusilla), Whimbrel (Numenius phaeopus), Atlantic Coast population of Least Tern (Sternula antillarum), and Greater Yellowlegs (Tringa melanoleuca), among other species. Additional coastal species that become listed for ESA protection could compromise ongoing efforts by USACE to meet mission objectives to maintain or enhance coastal structures and navigation capacity. A proactive approach to coastal engineering and sediment management along the Atlantic Coast is needed to provide and protect important habitat that will promote sustainable populations for imperiled shoreline-dependent species.

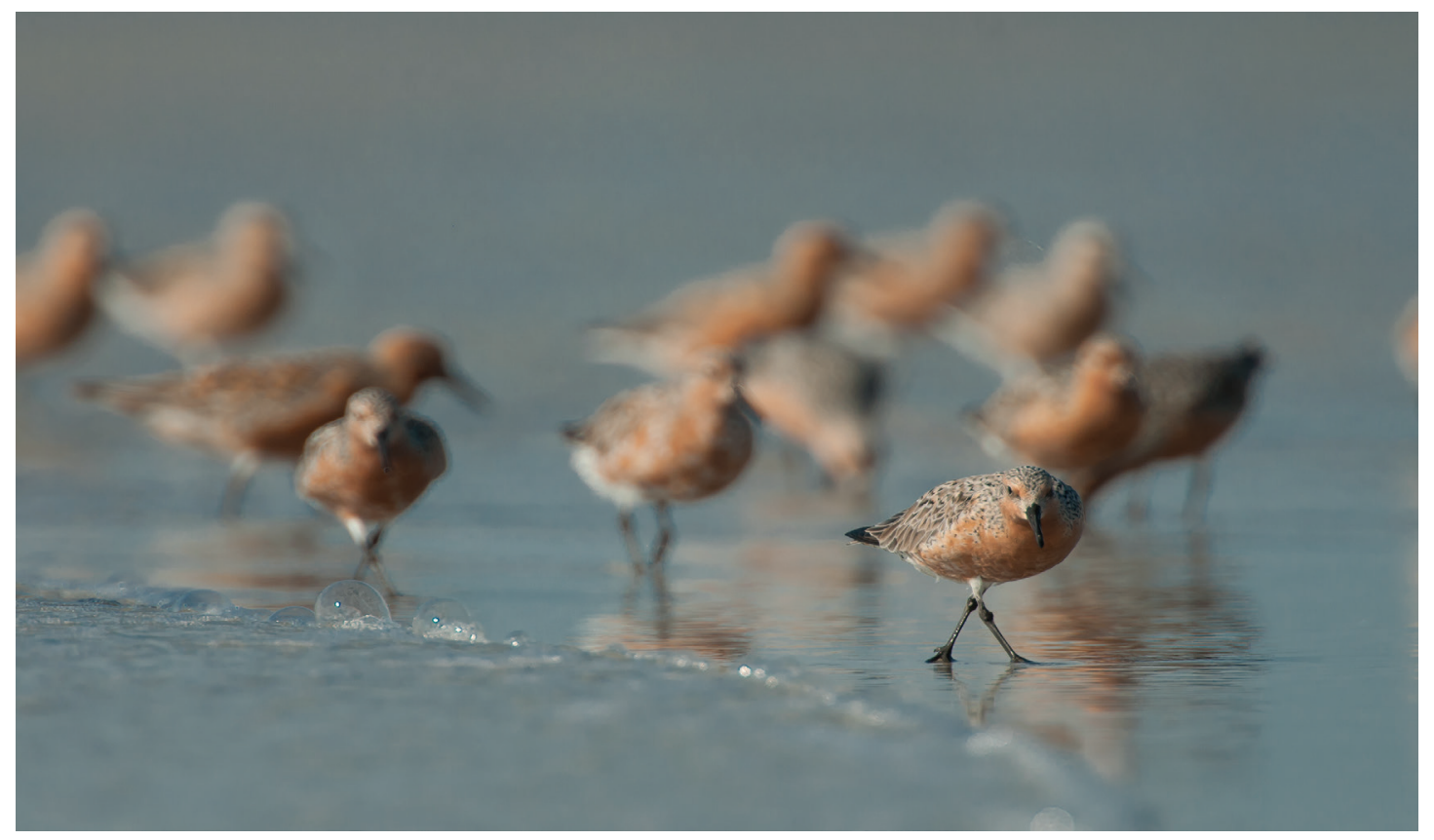

Figure 2. The rufa Red Knot (Calidris canutus rufa) was listed as threatened under the ESA in 2014. This is a migratory species dependent upon high-quality enroute stopover habitat along the Atlantic Coast (Photo Credit: Walker Golder, National Audubon Society, NC Field Office). 
INCOMPATIBLE COASTAL ENGINEERING ACTIVITIES: To promote effective strategies for managing coastal sediments and habitats for shoreline-dependent species, it is necessary to identify the primary coastal engineering actions that may negatively impact these species. Table 1 provides a list of common coastal engineering actions that likely have the most negative impacts on these species during some time of the year, but note that coastal engineering and conservation of habitats for shoreline-dependent species are not always incompatible, and the USACE is invested to integrating these two needs (Fischer et al. 2004, 2010; Guilfoyle et al. 2006, 2007). While negative impacts on sea turtles focus on nesting habitat and nest success, impacts on birds are more complicated. First, many migratory bird species do not breed or winter along the Atlantic Coast, but do require sufficient amount and quality of stopover habitat during spring and fall migration. Long distance migration is an essential feature of the life history of many of these birds. Many of these species breed in the Arctic regions of Canada and Alaska, and spend the winter in the Caribbean, Mexico, and Central and/or South America. Migration is a period of high mortality for these birds, especially for hatch-year individuals, and population demographics and sustainability require that sufficient high quality stopover areas be available (Newton 2004; Kirby et al. 2008). Without sufficient stopover habitat, the high energetic requirements for a successful migration may not be met, leading to an increase in mortality rates and population declines. Some of these migratory species winter along the Atlantic and Gulf Coasts, and their coastal wintering habitats also can be degraded by coastal engineering activities and expanding residential areas that reduce habitat and increase human disturbance (e.g., cats, dogs, pedestrians). While assessment of habitats for breeding birds can be determined by the numbers of nesting pairs and overall nesting success (e.g., number of fledged young per nest), the assessment of wintering and migratory habitats is more difficult. Efforts to create nonbreeding habitat may require some unpredictable time before birds locate and start using the habitat regularly. Also, while data on the abundance of shorebirds using migratory and wintering habitat is important, overall survival and physiological condition of birds using these habitats (Gibson et al. 2018) may provide better information on the quality of the habitat and its overall capacity to support and enhance non-breeding populations.

\begin{tabular}{|c|c|c|c|}
\hline Engineering Action & $\begin{array}{l}\text { Potential Impacts on } \\
\text { Shorebirds }\end{array}$ & $\begin{array}{l}\text { Impacts on Nesting } \\
\text { Sea Turtles }\end{array}$ & Consequences of Impacts \\
\hline Beach Nourishment & $\begin{array}{l}\text { Covers existing } \\
\text { intertidal zone prey } \\
\text { base; degrades or } \\
\text { reduces value of site } \\
\text { for foraging shorebirds } \\
\text { during all seasons. } \\
\text { (Properly engineered } \\
\text { beaches can enhance } \\
\text { nesting and foraging } \\
\text { habitats). }\end{array}$ & $\begin{array}{l}\text { May reduce nesting } \\
\text { by sea turtles if } \\
\text { incompatible sediment } \\
\text { sources are used, } \\
\text { and/or if slope and } \\
\text { beach topography are } \\
\text { no longer suitable for } \\
\text { nesting. }\end{array}$ & $\begin{array}{l}\text { Primarily affects shorebirds by } \\
\text { degrading foraging value of } \\
\text { beach, impacting reproductive } \\
\text { success and survival during } \\
\text { non-breeding seasons; initially } \\
\text { lowers nesting attempts and } \\
\text { overall success for sea turtles. } \\
\text { Nourished areas may require } \\
\text { several seasons to recover. }\end{array}$ \\
\hline
\end{tabular}




\begin{tabular}{||l|l|l|l||}
\hline Inlet Relocation & $\begin{array}{l}\text { Moving or altering } \\
\text { shoreline habitat may } \\
\text { reduce size or quality } \\
\text { of shorebird foraging } \\
\text { habitat during all } \\
\text { seasons. }\end{array}$ & $\begin{array}{l}\text { May move or alter } \\
\text { beach habitat; shifting } \\
\text { beach location or } \\
\text { altering shape/ } \\
\text { structure of beach } \\
\text { may reduce nesting. }\end{array}$ & $\begin{array}{l}\text { Degrading quality of foraging } \\
\text { habitat may negatively affect } \\
\text { survival and reproductive } \\
\text { success for shoreline- } \\
\text { dependent species; lowers } \\
\text { reproductive success of } \\
\text { nesting sea turtles. }\end{array}$ \\
\hline $\begin{array}{l}\text { Sea Wall, Riprap and } \\
\text { other Hard Structure } \\
\begin{array}{l}\text { Constructions to } \\
\text { Stabilize Shorelines }\end{array}\end{array}$ & $\begin{array}{l}\text { Immediately removes } \\
\text { potential foraging sites } \\
\text { for all shoreline- } \\
\text { dependent birds; may } \\
\text { disrupt natural } \\
\text { deposition patterns, } \\
\text { inhibiting formation of } \\
\text { dunes, sand spits, } \\
\text { inlets and other coastal } \\
\text { habitats }\end{array}$ & $\begin{array}{l}\text { May immediately alter } \\
\text { areas previously used } \\
\text { for nesting. }\end{array}$ & $\begin{array}{l}\text { Removes potential foraging } \\
\text { habitat for birds and nesting } \\
\text { habitat for sea turtles; } \\
\text { disruption of natural sediment } \\
\text { deposition patterns may } \\
\text { reduce or eliminate natural } \\
\text { formation of habitats used by } \\
\text { shoreline-dependent species }\end{array}$ \\
\hline
\end{tabular}

BEST MANAGEMENT PRACTICES FOR COASTAL ENGINEERING PROJECTS: The USACE needs improved approaches to offset potential negative impacts of coastal engineering and shoreline stabilization actions and that will create better conditions for shoreline-dependent birds, sea turtles, and other sensitive or rare flora and fauna. Such approaches, referred to as Best Management Practices (BMPs) (Rice 2009), need to be developed, tested and verified locally, and then implemented widely to provide guidelines that will help avoid, minimize, or mitigate negative impacts, or enhance positive impacts of coastal engineering projects along the Atlantic Coast. These BMPs should then be incorporated into the USACE planning, design, and construction stages of all coastal engineering projects. Pre- and post-project monitoring will be necessary to assess whether specific BMPs are benefiting targeted species as designed. BMPs also will likely need to be developed to address coastal engineering actions impacting specific coastal habitats including beaches, inlets, nearshore and offshore sites, barrier islands, dunes, estuaries, marshes, and mudflats. In addition, BMPs will need to be cost-effective to meet USACE mission objectives for coastal engineering projects. Increased engineering costs should not be more that 10 or 15 percent of baseline project expenditures. Therefore, it should be understood that BMPs implemented during a single project, by itself, may not provide great benefits to seasonal shoreline-dependent species. It is hoped that cumulative benefits of BMPs will be observable as a variety of BMPs are adopted and implemented in project after project, year-after-year, along the entire Atlantic Coast and other coastal regions in the U.S.

Atlantic Coast BMPs. BMPs have been developed for coastal stabilization efforts along the Atlantic Coast (Rice 2009). These BMPs have been adopted by the U.S. Fish and Wildlife Service (USFWS) for efforts to protect breeding Piping Plovers (Charadrius melodus), and will likely play a role in any Biological Opinions (BiOps) that concern the management or conservation of this species. These BMPs represent a first attempt to provide avoidance, minimization, and mitigation measures for the impacts of coastal stabilization on a breeding shorebird along the Atlantic Coast, but will need to be expanded to include other shorelinedependent species including impacts during the non-breeding seasons (Figure 3). However, these BMPs were not developed specifically for USACE coastal engineering projects, and therefore, these approaches will probably require significant modifications to be practical for most 
engineering actions without compromising mission objectives along the Atlantic Coast. Moreover, these BMPs have not yet received rigorous testing and assessment. Application of BMPs developed for conditions along the Atlantic Coast may not be applicable along the Pacific or Gulf Coasts. Table 2 outlines the BMPs from Rice (2009) and how they could be applied more widely to benefit shoreline-dependent species.

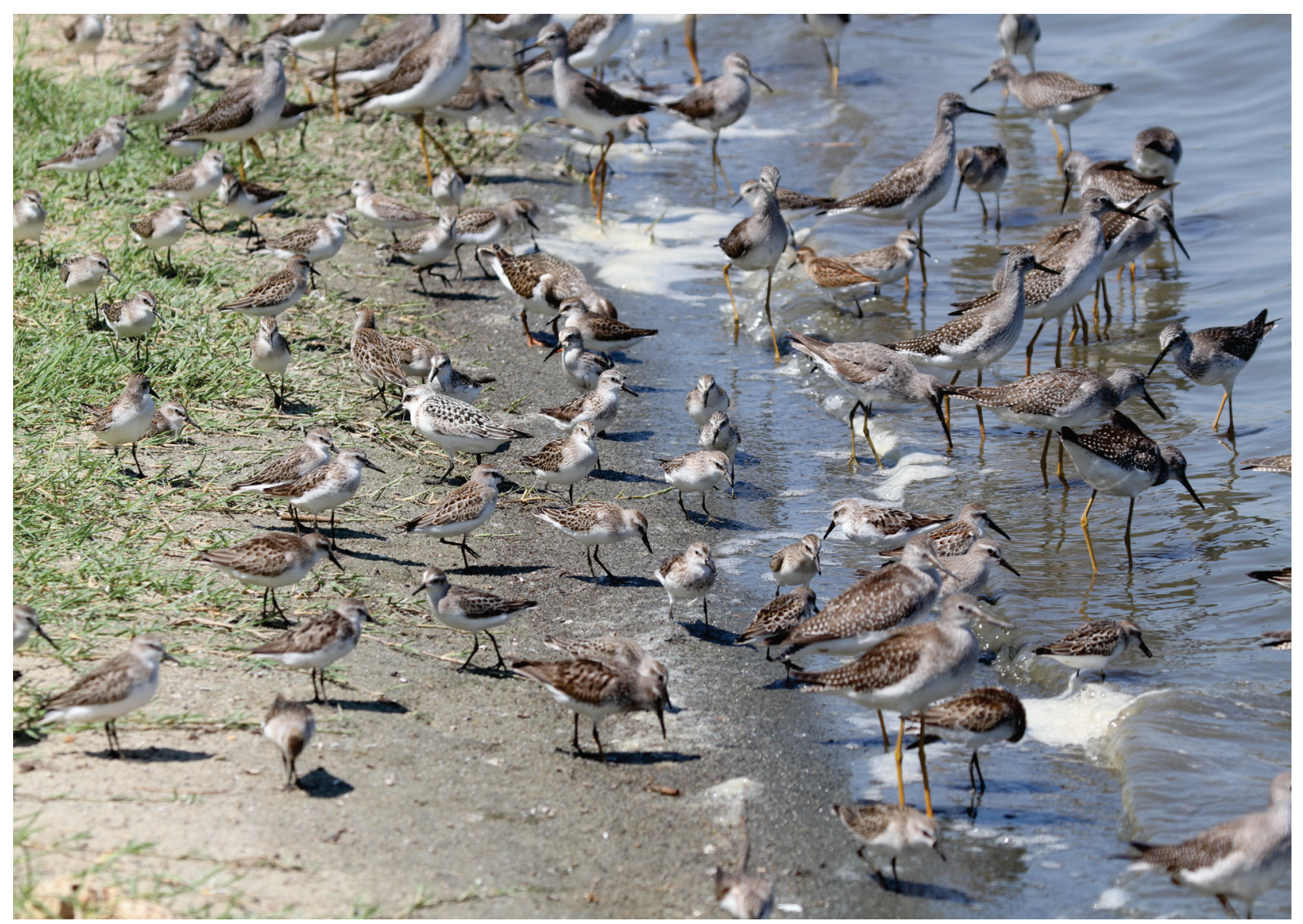

Figure 3. Mixed flocks of migratory shorebirds require sufficient foraging habitats along the Atlantic Coast including beaches, inlets, bayside shores, sand spits and mudflats (Photo Credit: J. Stevan Calver). 


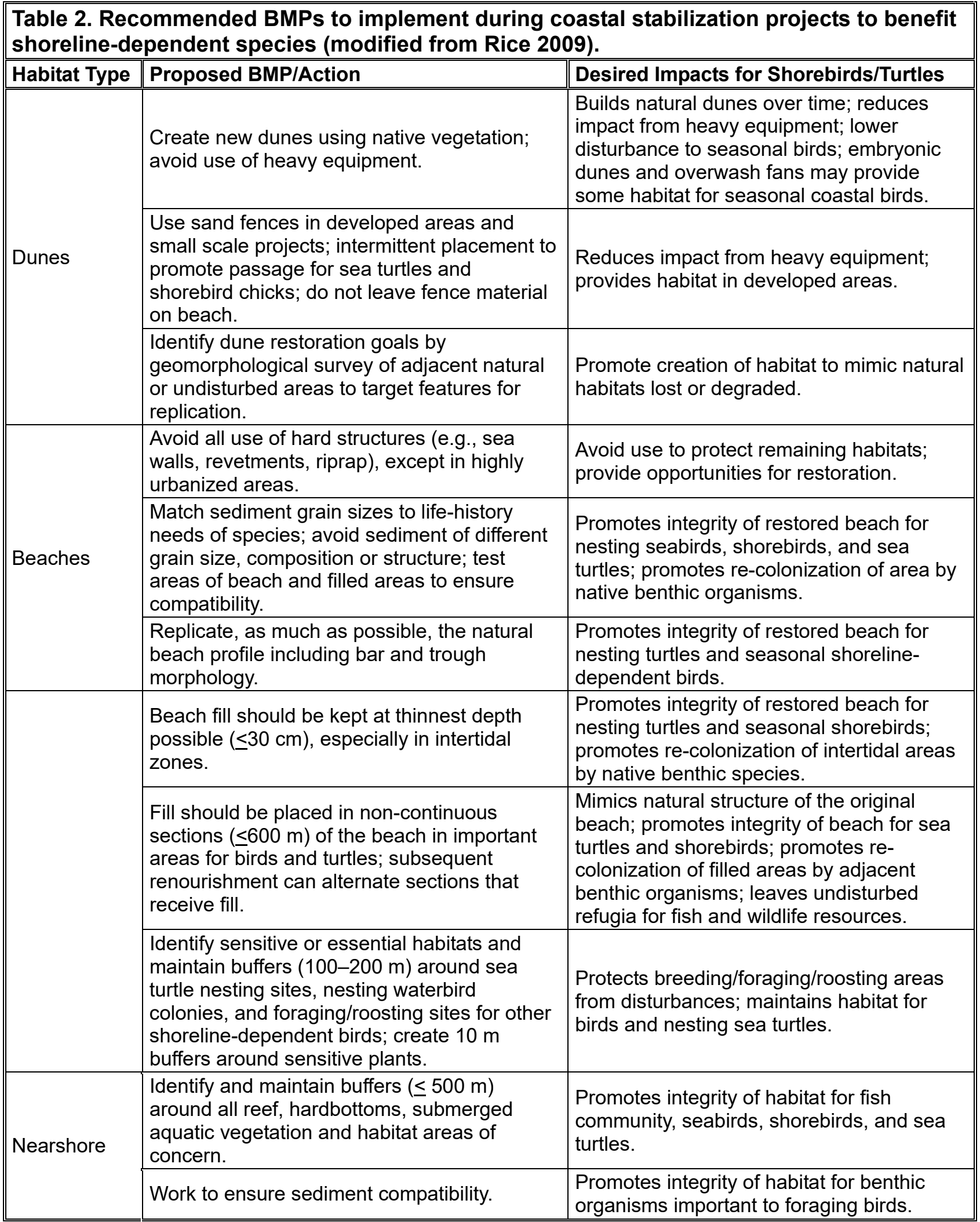




\begin{tabular}{|c|c|c|}
\hline & $\begin{array}{l}\text { Avoid use of heavy equipment; do not use } \\
\text { nearshore sandbars as sand sources for } \\
\text { beach nourishment projects. }\end{array}$ & $\begin{array}{l}\text { Promotes integrity of habitat for wildlife; } \\
\text { protects/lowers wave energy; reduces need } \\
\text { for future shoreline stabilization. }\end{array}$ \\
\hline \multirow[b]{2}{*}{ Offshore } & $\begin{array}{l}\text { Protect and buffer all reefs and hardbottom } \\
\text { habitats; locate areas mined for sediment } \\
\text { away from all sensitive habitats. }\end{array}$ & $\begin{array}{l}\text { Promotes integrity of habitat for fish and } \\
\text { wildlife. }\end{array}$ \\
\hline & $\begin{array}{l}\text { Mining efforts should not significantly alter } \\
\text { bathymetry; use shallow/staggered digs; } \\
\text { retain significant layer of sediment that } \\
\text { matches original surface. }\end{array}$ & $\begin{array}{l}\text { Promotes integrity of habitat for fish and } \\
\text { wildlife; retains areas as refugia and source } \\
\text { for recolonization of benthic organisms. }\end{array}$ \\
\hline \multirow{3}{*}{ Inlets } & $\begin{array}{l}\text { Minimize disturbance to inlet habitats; do not } \\
\text { dredge inlets for sediments or stabilize using } \\
\text { hard structures. }\end{array}$ & $\begin{array}{l}\text { Promotes integrity of habitat for seasonal } \\
\text { wildlife. }\end{array}$ \\
\hline & $\begin{array}{l}\text { In existing navigation channels, dredged } \\
\text { material can be relocated within inlet systems; } \\
\text { minimize disturbance with infrequent large } \\
\text { scale maintenance; use small scale impacts } \\
\text { as practical. }\end{array}$ & $\begin{array}{l}\text { Placement of sediment can downdrift to } \\
\text { beaches during wave and tidal processes; } \\
\text { replicates sediment processes to maintain } \\
\text { habitats below inlet; promotes integrity of } \\
\text { habitats for shorebirds and nesting turtles. }\end{array}$ \\
\hline & Prevent off-road vehicles on inlet resources. & $\begin{array}{l}\text { Promotes integrity of habitats for shorebirds } \\
\text { and nesting sea turtles. }\end{array}$ \\
\hline \multirow[t]{5}{*}{ Estuarine } & $\begin{array}{l}\text { Do not use sediments in estuaries as source } \\
\text { for stabilization projects; keep all dredged } \\
\text { material in local area. }\end{array}$ & $\begin{array}{l}\text { Protects foraging habitats for shoreline- } \\
\text { dependent birds and protects benthic and } \\
\text { fish communities. }\end{array}$ \\
\hline & $\begin{array}{l}\text { Do not bury marshes, benthic communities, } \\
\text { oyster reefs, clam beds, or other valuable } \\
\text { benthic and fish habitats. }\end{array}$ & $\begin{array}{l}\text { Protects foraging habitat for shoreline- } \\
\text { dependent birds; protects sensitive habitats } \\
\text { for benthic and fish communities. }\end{array}$ \\
\hline & Maintain overwash material, fans and flats. & $\begin{array}{l}\text { Promotes integrity of habitat for seasonal } \\
\text { wildlife; protects potential nesting habitat for } \\
\text { turtles. }\end{array}$ \\
\hline & $\begin{array}{l}\text { Do not use hard structures along estuarine } \\
\text { shorelines. }\end{array}$ & $\begin{array}{l}\text { Protects shoreline habitats for foraging birds } \\
\text { and potential nesting habitat for turtles. }\end{array}$ \\
\hline & $\begin{array}{l}\text { Finger canals and sand spits should not be } \\
\text { dredged in estuarine and bayside habitats. }\end{array}$ & $\begin{array}{l}\text { Protect foraging, roosting and loafing } \\
\text { habitat for shoreline dependent birds; } \\
\text { protects potential nesting habitat for turtles; } \\
\text { protects habitat for benthic and fish } \\
\text { communities. }\end{array}$ \\
\hline
\end{tabular}

Pacific Coast BMPs. The USACE Los Angeles District led the development of BMPs for the threatened Western Snowy Plover (Charadrius alexandrines nivosus) along the California Coast. These BMPs were designed to avoid and minimize impacts of maintenance dredging and deposition activities largely on non-breeding Western Snowy Plovers (Ryan and Hamilton 2009; Merkel and Associates 2017). BMPs were developed for maintenance dredging and beach nourishment operations at Oceanside Harbor, CA (Merkel and Associates 2017) and were implemented prior to project initiation and before any movement of construction equipment or creation of debris. These BMPs were developed for conditions along the Pacific Coast and may not be applicable for conditions along the Atlantic or Gulf Coasts. Key elements of the BMPs to protect Western Snowy Plovers included the following (from Merkel and Associates 2017): 
1. Project site will be monitored daily for presence of plovers and other protected shorebirds. Monitors will inform when birds are in the work area; efforts will be made to avoid disturbance and work will not continue until birds are out of work area.

2. If an active nest is discovered, no work will occur in area until young have fledged and are independent from adults.

3. Vehicles and equipment will be limited to the installation, maintenance, and removal of discharge pipeline and facilities, and trips to monitor beach discharge operations.

4. During all dredged pipeline activities (including mobilization, moving, maintenance, and demobilization), biological monitors will survey area for plovers and other protected birds prior to contractor entry and remain on site during all activities.

5. Beach re-contouring during dredge pipeline use or demobilization is limited to footprint of $50 \mathrm{ft}$ wide corridor. No beach combing after pipeline demobilization is permitted.

6. During activities, number of vehicle trips shall be minimized to extent possible.

7. Vehicle use on approved beach areas is limited to activities associated with dredging operations; no recreational use by the contractor is authorized.

8. The biological monitor shall contact local law enforcement if public or dogs are observed in the exclusion area.

Efforts to minimize disturbance of Western Snowy Plovers focus on reducing or eliminating the flushing of roosting or foraging birds. During dredging and deposition, few or no disturbances were noted, but birds often were disturbed by local residents, unleashed dogs, and activities of other local county employees (Ryan and Hamilton 2009). While these efforts should successfully minimize impacts on birds during dredging and nourishment operations, the USACE should work in closer collaboration with local authorities and municipalities to ensure enforcement of restrictions on public access to areas utilized by sensitive birds and other shoreline-dependent species. In addition, more research may be needed to ensure that efforts provide population sustainability for non-breeding populations comparable to non-impacted areas.

Gulf Coast BMPs. Specific recommendations to protect shorebirds, particularly Piping Plovers, and other shoreline-dependent species, were developed by the USFWS and included in BiOps related to efforts along the Florida Gulf Coast along the Pensacola and Panama City Beaches (USFWS 2014). These recommendations may be formulated as BMPs; however, these BMPs may not be applicable along the Pacific or Atlantic coasts. Examples of specific recommendations include the following:

1. Avoid removing wrack line material from relatively undeveloped portions of the beach.

2. Identify and protect all areas designated as Piping Plover Optimal Habitats.

3. Protection of geomorphologic processes that lead to habitat renewal, including sand placement in areas that will not impede washover areas and avoid filling ephemeral pools.

4. Prior to disposition of dredged material, qualified personnel will mark all areas to be avoided using obvious identifiers.

5. Conduct bi-monthly surveys for Piping Plovers in the inlet area including shoals, bayside flats, bayside and ocean beaches using USFWS guidelines.

6. Post-construction bird surveys shall occur twice per month and annual spatial measurements of optimal habitat is to occur six months after sand placement; surveys shall continue for no less than five years. 
7. Minimize all beach driving activities for law enforcement, beach patrol and beach vendors.

8. Post and rope off designated Piping Plover roosting and foraging areas.

9. Place educational signs where appropriate.

10. Prohibit planting of vegetation in Optimal Piping Plover habitat.

11. Within $400 \mathrm{~m}$ of project site, install predator-proof trash receptacles.

12. Minimize occurrence of dredging in adjacent inlets unless for emergency purposes.

BMPs for shoreline-dependent species have not yet been developed for other coastal habitats, including barrier islands, estuaries, salt marshes or mud flats. Coastal engineering projects that adopt approaches to create, protect or enhance these habitats will need pre- and post-project monitoring to test and evaluate successes and failures such that these respective approaches can be modified and optimized overtime. This approach will be consistent with adaptive management policies practiced by USACE Districts. In addition, efforts within the USACE Dredging Operations Environmental Research (DOER) and EWN programs have developed natural and nature-based designs along coastal shorelines to promote coastal resilience (Bridges et al. 2015). Natural and nature-based features (https:/lewn.el.erdc.dren.mil/nnbf.html\#) seek to use coastal engineering approaches that mimic natural systems on shorelines, barrier islands, dune systems, and other coastal habitats to provide natural stabilization protection from storm surge and sea-level rise. Several of the approaches described by Bridges et al. (2015) target habitat along coastal shorelines to benefit threatened and endangered species (TES). These approaches could be formulated as BMPs to be developed for seasonal shoreline-dependent species, tested and assessed, and then made available for USACE Districts along the Atlantic, Gulf and Pacific Coasts to use during engineering project planning, design, construction, and maintenance activities. For example, while Rice (2009) strongly recommends the exclusion of hard structures along the Atlantic Coast for shoreline stabilization, particularly in inlets, natural and nature-based substitutions for hard structures may be able to provide habitat for some species (Bridges et al. 2015).

BENEFICIAL USES OF DREDGED MATERIAL: The USACE has a long history of utilizing dredged material to benefit coastal and riverine bird communities (Fischer et al. 2004, 2010; Guilfoyle et al. 2006, 2007). Designing and implementing projects that use dredged material for environmental benefits can enhance coastal resilience and provide opportunities to create habitats for many coastal species (U.S. Environmental Protection Agency (EPA) 2007). Dredged material (e.g., from maintenance dredging) has been used to create over 2,000 small islands along the Atlantic Coast. Many shorebirds now depend on these islands for breeding, with some islands supporting large proportions of the local, regional and global populations (Fischer et al. 2004, 2010; Guilfoyle et al. 2006, 2007). Extensive research on the seasonal use and distribution of birds nesting on these islands was conducted in the latter decades of the $20^{\text {th }}$ century by the USACE Dredged Material Research Program (DMRP) (Soots and Landin 1978). Examples of islands created with dredged material that provide important habitats for many coastal bird species today, include Queen Bess Island, LA, and Gaillard Island, AL. These islands, and others, are well documented to support critical nesting habitat for many imperiled coastal birds, including Gull-billed Terns (Gelochelidon nilotica), Least Tern, American Oystercatcher (Haematopus palliatus) and Brown Pelican (Pelecanus occidentalis) (Soots and Landin 1978; Fischer et al. 2004, 2010; Guilfoyle et al. 2006, 2007). These islands likely provide important habitat for a wide variety of migratory and wintering birds, but data on bird communities during the non-breeding seasons generally are poor or not available. Specific 
aspects of coastal islands, including sediment characteristics, size, extent, shape, and topography (Golder et al. 2008) are likely to influence the frequency of use by shoreline-dependent birds. Also, plant succession on these islands can reduce, degrade, or eliminate habitat for many breeding coastal birds. Vegetation management via herbicide or mechanical removal, or by reapplication of dredged material on these islands, may serve to maintain habitat for some birds, but management actions are typically irregular or non-existent for many coastal islands. In addition, many islands are subjected to erosion from sea-level rise and riverine levee systems that reduce the flow of sediments into coastal bays and estuaries. The current status and habitat value of many of these islands for birds needs to be investigated further.

Beach nourishment activities by the USACE typically provide dredged material for highly eroded beaches, either in high recreational use areas, or sites in need of additional shoreline protection after storms. Beach nourishment can also be used to rebuild beaches for a variety of shoreline-dependent birds and sea turtles (Dickerson et al. 2006) (Figure 4), and BMPs can be developed and standardized for projects to benefit these species (Table 2). These BMPs should address the physical (e.g., applying appropriate sediments that closely approximate the size, topography, structure and composition of sediments of the local beach system) (Dickerson et al. 2006), spatial (size and extent of projects), and temporal considerations (e.g., avoid actions during critical nesting, migrating or wintering seasons for shorebirds and recruitment periods for infaunal benthic communities) (Rosov et al. 2016).

RESEARCH AND MONITORING NEEDS: More research is needed to develop and test BMPs that will be effective in supporting shoreline-dependent species throughout their annual life cycle. Specific features for creating successful nesting habitat for sea turtles are better understood (Dickerson et al. 2006) than for seasonal shorebirds, but BMPs need to be standardized and implemented widely in USACE coastal engineering projects to promote demonstrable benefits to shoreline dependent populations. The development and testing of BMPs need to begin in pre-project planning and monitoring, and continue after the engineering action has been completed. Habitat needs for many migratory and wintering shorebirds and seabirds are poorly understood; however, Piping Plovers associated with disturbance in coastal habitats, including coastal habitat modifications, have been shown to have lower survival and be in poorer physiological condition during the non-breeding season (Gibson et al. 2018). Assessing shortterm benefits of BMPs to non-breeding shoreline-dependent birds will be difficult and results may be unclear initially. Migratory shorebirds often follow weather frontal systems and may bypass quality stopover areas to benefit from conditions that promote timely arrival on breeding or wintering grounds. Size, shape and position of quality stopover habitat in the landscape may also impact use by migratory shorebirds (Gillespie et al. 2017). Juvenile and hatch-year birds typically experience higher mortality than adults, but significant changes to coastal habitats may negatively impact older, more experienced birds as well. For example, the rufa Red Knot, which was listed as federally Threatened under ESA in 2014, is known to focus its diet on eggs of horseshoe crabs (Limulus polyphemus) during spring migration in the Delaware Bay and elsewhere along the Atlantic Coast. Overharvesting of horseshoe crabs has reduced migratory rufa Red Knot populations by over $70 \%$, with significant mortality among adults (Niles et al. 2009). Poor stopover habitat may incur adult mortality enroute during migration, or it may lead to poor reproductive success upon arrival to the breeding grounds or lower survival upon arrival on the wintering grounds. While numerous states have enacted stricter harvest regulations for 
horseshoe crabs (Niles et al., 2009), higher egg abundance and documented increases in rufa Red Knot migratory populations have not materialized. However, horseshoe crabs require nearly ten years to reach sexual maturity, so it could take many years before populations are restored. In the meantime, populations of rufa Red Knots and other migratory shorebirds that rely on this food resource remain vulnerable. While efforts to create high-quality stopover habitat may take years to be established, once the sites are adopted by shorebirds, they will likely be used regularly.

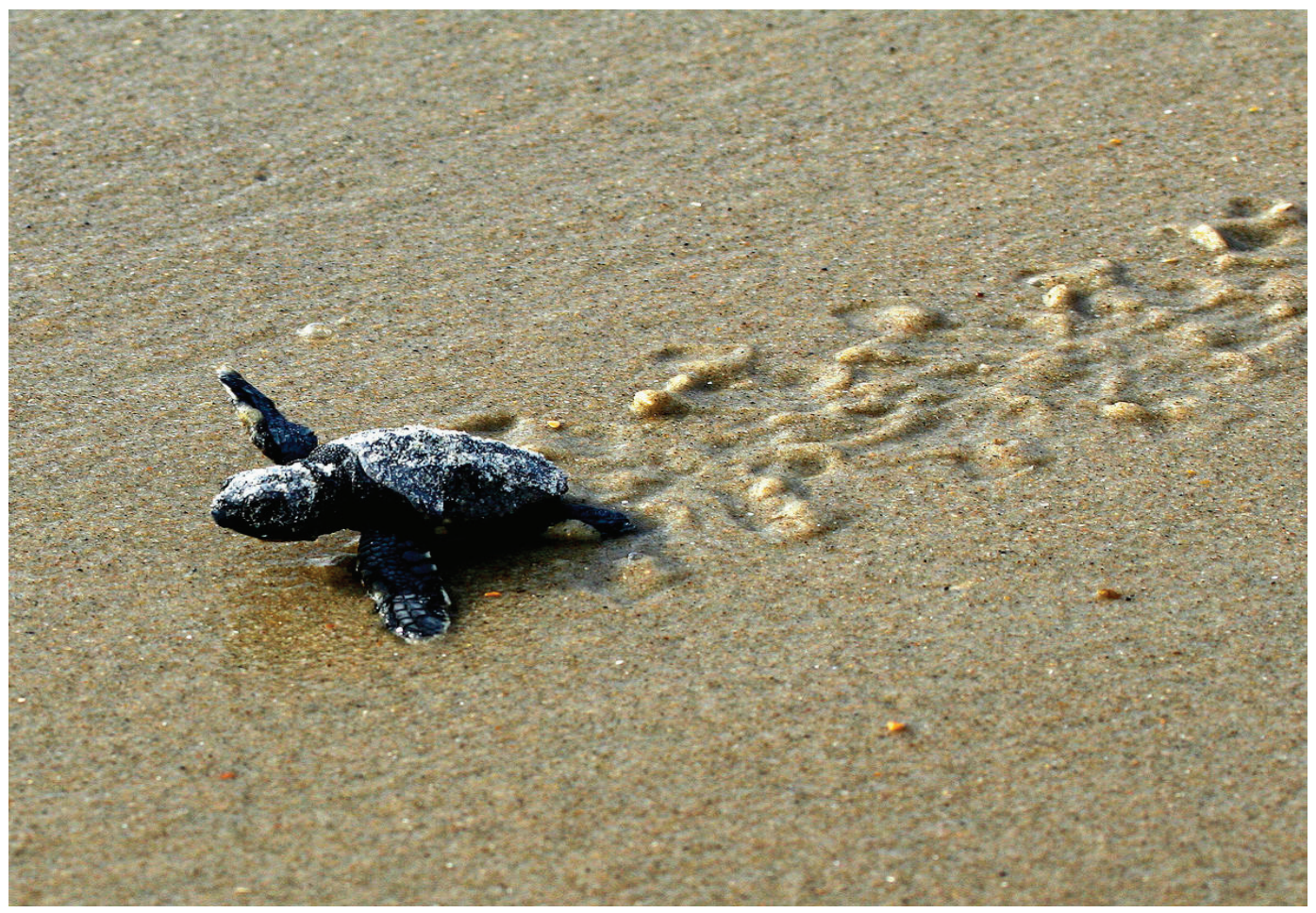

Figure 4. Beach nourishment has the potential to create suitable nesting habitat for sea turtles if the correct sediment sources is used, and if the shape, contour, and access to the beach matches the natural topography (Dickerson et al. 2006) (Photo Credit: Public Domain image, U.S. Geological Survey, https://www.usgs.gov/media/images/loggerhead-hatchling-makes-its-way-sea).

A key element of BMPs for shoreline-dependent birds is the protection or restoration of the intertidal benthic organisms upon which these birds feed. Following beach nourishment, several seasons may be necessary for restoration of the benthic community under some conditions (Rakocinsiki et al. 1996; Burlas et al. 2001; Colosio et al. 2007; Rosov et al. 2016; Wooldridge et al. 2016). Often, the impacts of beach nourishment on the benthic community is difficult to discern, since most permitting and monitoring requirements lack scientific rigor in the final reports (Peterson and Bishop 2005). However, monitoring efforts on benthic communities have documented recovery of the community in one year or less when proper sediment is used and when timing of the nourishment operation does not conflict with peak larval recruitment or natural seasonal infaunal declines (Rosov et al. 2016; Wooldridge et al. 2016). Moreover, monitoring of bird communities has shown that if coastal engineering projects can create a diverse mix of breeding, foraging, and loafing habitat, particularly moist substrate habitats in bay-side intertidal areas with ephemeral pools, moist overwash zones, and mudflats, then longterm negative impacts may be minimized (Guilfoyle et al. 2006, 2007). 
Coastal engineering impacts on birds will need to be assessed by a before-after control-impact (BACI) design where pre- and post-project monitoring of species richness and abundance metrics are undertaken. The goals of implementing BMPs should be to reduce the difference in these metrics between impacted and control sites. Quantifying foraging behavior, including number of prey consumed per unit time (Van Gils et al. 2006), may also convey information on the success of BMPs to successfully create high quality foraging habitat. Assessing physiological condition and application of an Integrated Population Modeling (IPM) approach can provide information on shorebird survival during the non-breeding season (Gibson et al. 2018). These efforts should focus on documenting the success of BMP implementation to create and enhance coastal habitats for breeding and nonbreeding shoreline-dependent birds and nesting sea turtles. Successful monitoring efforts can also act to promote adaptive management responses to alter BMPs as necessary to meet goals to improve conditions for target populations.

ESA SECTION 7(a)(1) CONSERVATION PLANNING: The USACE is working on new approaches to address the conservation and recovery of Federally listed species that impact mission areas. The ERDC-EL Threatened and Endangered Species Team (TEST) is investigating the use of Endangered Species Act Section 7(a)(1) conservation planning (Hartfield et al. 2017; Li 2017) as a viable means to reduce long-term expenditures, and reduce mission impacts from management actions taken for TES. The USACE has recently advocated a commitment to the Section 7(a)(1) conservation planning approach that calls for a proactive management of species listed under the ESA (Hartfield et al. 2017), while also managing lands and implementing projects so as to minimize the probability that other rare or sensitive species will become listed. Increased costs already associated with species such as the interior population of Least Terns, coastal Piping Plovers, and the recently listed rufa Red Knot, and confusion on how to manage future potential listings, has created a strong need for the USACE to determine how and when to implement the Section 7(a)(1) process, and proactive management of coastal resources for imperiled shoreline-dependent species provides one such opportunity. Moreover, the Section 7(a)(1) process requires a multi-agency collaboration that works hand-in-hand with other stakeholders. The Atlantic Flyway Shorebird Initiative (AFSI) is a collaborative organization of international and national government agencies, universities, and non-government organizations dedicated to the conservation of breeding, migratory and wintering shorebirds along the Atlantic Flyway. This effort is hemispheric in scope, addressing shorebird conservation issues on arctic breeding grounds, migratory habitat along the Atlantic Coast, and wintering habitats in Central and South America. By working proactively with AFSI, the USACE can address concerns of stakeholders involved with shorebird conservation. Numerous projects along the Atlantic Coast, funded by the National Fish and Wildlife Foundation (NFWF) for AFSI, provide opportunities for data sharing, project development, and long-term monitoring to assess success, as demonstrated by the effort to improve population metrics for the America Oystercatcher (Ens et al. 2017). The AFSI already provides organizational and collaborative engagements to meet the needs of critical stakeholders. In addition, because the AFSI works at the international and hemispheric scales, this ensures the USACE will not solely bear the burden of creating and assessing habitats for shoreline dependent species along the Atlantic Coast.

DISCUSSION: The USACE needs to find new approaches for conducting coastal engineering operations along the Atlantic Coast. Many TES and other rare or sensitive species are dependent on benthic and intertidal features of the coastal sediments that provide critical breeding, foraging, 
roosting and loafing habitats during the breeding, winter, and migratory seasons. Coastal habitats used by these species may be degraded by USACE coastal engineering operations that are essential for the creation, enhancement and maintenance of our coastal infrastructure. This TN introduces the issues concerning USACE coastal engineering operations and potential BMPs that could be developed or refined to avoid, minimize or mitigate the impacts of engineering for shoreline-dependent species. Moreover, efforts to create or enhance habitats for TES and other rare or sensitive species could be included in a ESA Section 7(A)(1) conservation consultation process with the USFWS. Working proactively with the USFWS and other stakeholders, including the AFSI, could provide more flexibility to meet mission objectives along the Atlantic Coast, lower long-term costs associated with management of TES, while acting to provide demonstrable benefits to target populations. Working proactively with other agencies can assist with pre- and post-project monitoring that will be necessary to test and assess effectiveness of BMPs for coastal engineering projects. Another benefit would be to lower probability that other rare or sensitive species may become listed under ESA.

Much more work is needed to effectively manage coastal habitats for shoreline-dependent species during USACE coastal engineering projects along the Atlantic Coast. First, existing BMPs will have to be modified to be cost-effective for USACE engineering operations and new BMPs may be needed to address specific coastal habitats or mission conditions along the Atlantic, Pacific, or Gulf Coasts. The pre- and post-project impacts of BMPs will need to be assessed to document benefits for TES and other rare and sensitive species. Second, consultation with the USFWS will be needed to determine credit under the ESA Section 7(A)(1) process and to establish future agreements that may lead to reduced restrictions from environmental windows, or other incentive-based options, in exchange for efforts that provide demonstrable benefits to target populations. Third, effective BMPs will need to be identified, clearly described in proper context of USACE mission objectives, and included in coastal engineering manuals or other documents. This information will need to be distributed to various USACE District offices along the Atlantic, Pacific and Gulf Coasts as needed. The approach outlined in this TN provides the best option to restore and protect our nation's imperiled shorebird and sea turtle populations, and other shoreline-dependent species, along the Atlantic Coast.

SUMMARY: The USACE is mandated to create, maintain, and enhance our coastal infrastructure, including ports and harbors, and the ICWW. To meet this mission goal, the USACE designs, plans, and implements coastal engineering projects along the Atlantic Coast. However, these actions can alter and degrade habitats for TES, and other sensitive or rare shoreline-dependent species that utilize coastal habitats. Engineering actions likely to negatively impact these species are introduced (e.g., dredged material deposition, shoreline stabilization), along with a series of proposed BMPs to mitigate, enhance, or create habitat for imperiled shoreline-dependent species such as shorebirds, seabirds, and sea turtles. Research and long-term monitoring are needed to test effectiveness of BMPs to provide quality seasonal habitats that serve to benefit and support sustaining populations. Integrating these approaches in concert with proactive actions under the ESA Section 7(a)(1) conservation planning process with the USFWS provides an opportunity for the USACE to meet mission goals and increase flexibility during coastal engineering operations, while providing demonstrable benefits to listed species and reducing the probability that other species will become listed. 
ACKNOWLEDGEMENTS: Funding was provided by the Ecosystem Management and Restoration Research Program (EMRRP). The Technical Director for the EMMRP Program is Dr. Trudy Estes. Technical reviews were provided by Dr. Burton Suedel, and Ms. Denise Lindsay, both of ERDC/EL, and Dr. Tim Welp of ERDC/CHL.

POINTS OF CONTACT: For additional information, contact Dr. Michael P. Guilfoyle (601634-3432; Michael.P.Guilfoyle@usace.army.mil), Dr. Richard A. Fischer (502-641-7824; Richard.A.Fischer@usace.army.mil), or the Program Manager of the Ecosystem Management and Restoration Research Program (EMRRP), Dr. Trudy Estes (601-634-2125; Trudy.J.Estes@usace.army.mil).

This technical note should be cited as follows:

Guilfoyle, M. P., J. F. Jung, R. A. Fischer, and D. D. Dickerson. 2019. Developing Best Management Practices for Coastal Engineering Projects that Benefit Atlantic Coast Shoreline-dependent Species. EMRRP Technical Notes Collection. ERDC/TN EMRRP-SI-38. Vicksburg, MS: U.S. Army Engineer Research and Development Center. http://el.erdc.usace.army.mil/emrrp/techran.html

\section{REFERENCES}

Bridges, T. S. P. W. Wagner, K. A. Burkes-Copes, M. E. Bates, Z. A. Collier, C. J. Fischenich, J. Z. Gailani, L. D. Leuck, C. D. Piercy, J. D. Rosati, E. J. Russo, D. J. Shafer, B. C. Suedel, E. A. Vuxton, and T. V. Wamsley. 2015. Use of Natural and Nature-Based Features (NNBF) for Coastal Resilience. ERDC/EL-SR-15-1. Vicksburg, MS: U.S. Army Engineer Research and Development Center. https://dots.el.erdc.dren.mil/elpubs/pdf/sr-15-1.pdf.

Burlas, M., G. L. Ray, and D. G. Clarke. 2001. The New York District's biological monitoring program for the Atlantic coast of New Jersey, Ashbury Park to Manasquan Section beach erosion control project. Final Report, prepared by U.S. Army Engineer Research and Development Center for U.S. Army Engineer District, New York.

Collins, J. T., R. Powell, and R. Conant. 1998. Peterson Field Guide to Reptiles and Amphibians of Eastern and Central North America. New York, NY: Houghton Mifflin Company.

Colosio, F., M. Abbiati, and L. Airoldi. 2007. Effects of beach nourishment con sediments and benthic assemblages. Marine Pollution Bulletin 54(8):1197-1206. https://doi.org/10.1016/j.marpolbul.2007.04.007.

Dickerson, D. D., J. Smith, M. Wolters, C. Theriot, K. J. Reine, and J. Dolan. 2006. A review of beach nourishment impacts on marine turtles. Shore and Beach 75(1):1-8.

Ens, B. J., and L. G. Underhill. 2014. Synthesis of oystercatcher conservation assessments: General lessons and recommendations. International Wader Studies 20:5-22.

Fischer, R. A., M. P. Guilfoyle, C. A. Lott, and D. N. Pashley. 2004. Application of dredged material disposal for enhancement of bird habitat: Past and current efforts by the U.S. Army Corps of Engineers. Pages 95-103 In C. A. Fleming, ed., $3^{\text {rd }}$ Missouri River and North American Piping Plover and Least Tern Symposium, Sioux City: NE.

Fischer, R. A., M. P. Guilfoyle, C. Lott, and A. Hannes. 2010. Engineering along coastlines and interior rivers - how is the U.S. Army Corps of Engineers integrating bird conservation with dredging/beach nourishment activities in North America? Beijing, China: $19^{\text {th }}$ World Dredging Congress. 1122-1135. 
Gibson, D., M. K. Chaplin, K. L. Hunt, M. J. Friedrich, C. E. Weithman, L. M. Addison, V. Cavalieri, S. Coleman, F. J. Cuthbert, J. D. Fraser, W. Golder, D. Hoffman, S. M. Karpanty, A. Van Zoeren, and D. H. Catlin. 2018. Impacts of anthropogenic disturbance on non-breeding body condition, survival, and population growth of a shorebird. Condor 120(3):566-580. https://doi.org/10.1650/CONDOR-17-148.1.

Gillespie, C. R., and J. J. Fontaine. 2017. Shorebird stopover habitat decisions in a changing landscape. Journal of Wildlife Management 81(6):1051-1062. https://doi.org/10.1002/jwmg.21271.

Golder, W., D. Allen, S. Cameron, and T. Wilder. 2008. Dredged Material as a Tool for Management of Tern and Skimmer Nesting Habitat. DOER Technical Notes Collection ERDC TN-DOER-E24. Vicksburg, MS. U.S. Army Engineer Research and Development Center. https://erdc-library.erdc.dren.mil/xmlui/handle/11681/8757.

Guilfoyle, M. P., R. A. Fischer, D. N. Pashley, and C. A. Lott. 2006. Summary of First Regional Workshop on Dredging, Beach Nourishment, and Birds on the South Atlantic Coast. DOER Technical Report ERDC/EL TR06-10. Vicksburg, MS. U.S. Army Engineer Research and Development Center. https://el.erdc.dren.mil/elpubs/pdf/trel06-10.pdf.

Guilfoyle, M. P., R. A. Fischer, D. N. Pashley, and C. A. Lott. 2007. Summary of Second Regional Workshop on Dredging, Beach Nourishment, and Birds on the South Atlantic Coast. DOER Technical Report ERDC/EL TR07-26. Vicksburg, MS. U.S. Army Engineer Research and Development Center. https://el.erdc.dren.mil/elpubs/pdf/trel07-26.pdf.

Harrington, B. R. 2008. Coastal Inlets as Strategic Habitat for Shorebirds in the Southeastern United States. DOER Technical Notes Collection ERDC TN-DOER-E25, Vicksburg, MS. U.S. Army Engineer Research and Development Center. https://erdc-library.erdc.dren.mil/xmlui/handle/11681/8756.

Hartfield, P., J. G. Brown, and R. A. Fischer. 2017. The Role of Interagency Cooperation in the Conservation of Threatened and Endangered Species. DOER technical Notes Collection. ERDC TN-DOER-40. Vicksburg, MS. U.S. Army Engineer Research and Development Center. https://doer.el.erdc.dren.mil/notes reports.html.

Kirby, J. S., A. J. Statterfield, S. H. M. Butchart, M. I. Evans, R. F. A. Grimmett, V. R. Jones, J. O’Sullivan, G. M. Tucker, and I. Newton. 2008. Key conservation issues for migratory land- and waterbird species on the world's major flyways. Bird Conservation International 18:S49-S73. https://doi.org/10.1017/S0959270908000439.

Li, Y-W. 2017. Invigorating a neglected tool for endangered species recover. American Bar Association: Section of Environment, Energy, and Resources. American Bar Association Section of Environment, Energy, and Resources: Endangered Species Committee Newsletter 16(1):6-9.

Mazaris, A. D., G. Schofield, C. Gkazinou, V. Almpanidou, and G. C. Hays. 2017. Global sea turtle conservation successes. Science Advances 3 2017(3):e1600730.

Merkel and Associates, Inc. 2017. Final Oceanside Harbor (2017) maintenance dredging, San Diego County, CA: Western Snowy Plover monitoring and avoidance plan. Prepared for Manson Construction, Long Beach, CA.

Newton, I. 2004. Population limitation in migrants. British Ornithologists' Union, Ibis 146:197-226.

Niles, L. J., J. J. Bart, H. P. Sitters, A. D. Dey, K. E. Clark, P. W. Atkinson, A. J, Baker, K. A. Bennett, K. S. Kalasz, N. A. Clark, J. Clark, S. Gillings, A. S. Gates, P. M. Gonzalez, D. E. Hernandez, C. D. T. Minton, R. L. G. Morrison, R. R. Port, R. K. Ross, and C. R. Veitch. 2009. Effects of horseshoe crab harvest in Delaware Bay on Red Knots: Are harvest restrictions working? Bioscience 59(2):153-164. https://doi.org/10.1525/bio.2009.59.2.8.

Peterson, C. H., and M. J. Bishop. 2005. Assessing the environmental impacts of beach nourishment. Bioscience 55(10):887-896. https://doi.org/10.1641/0006-3568(2005)055[0887:ATEIOB]2.0.CO;2.

Rakocinski, C., R. Heard, S. LeCroy, J. McLelland, and T. Simmons. 1996. Responses by microbenthic assemblages to extensive beach restoration at Perdido Key, FL, USA. Journal of Coastal Research 12(1):326-353. https://www.jstor.org/stable/4298484

Rice, T. M. 2009. Best management practices for shoreline stabilization to avoid and minimize adverse environmental impacts. Prepared for the U.S. Fish and Wildlife Service, Panama City Ecological Services Field Office by Terwilliger Consulting, Inc., Locustville, VA. 
Rosov, B., S. Bush, T. R. Briggs, and N. Elko. 2016. The state of understanding the impacts of beach nourishment activities on infaunal communities. Shore and Beach 84(3):51-55.

Ryan, T., and R. Hamilton. 2009. Surfside beach sand replenishment project Western Snowy Plover Monitoring. Final Report. Prepared for Manson Construction, San Pedro, CA.

Sibley, D. S. 2016. The Sibley Field Guide to Birds of Eastern North America: Second Edition. New York, NY: Alfred A. Knopf, Inc.

Soots, R. F., Jr., and M. C. Landin. 1978. Development and Management of Avian Habitat on Dredged Material Islands. DMRP Technical Report DS-78-18. Vicksburg, MS: U.S. Army Engineer Research and Development Center.

U.S. Environmental Protection Agency (EPA). 2007. Identifying, planning, and financing beneficial use projects using dredged material: Beneficial use planning manual. Washington, DC: U.S. Environmental Protection Agency. https:/www.epa.gov/sites/production/files/201508/documents/identifying planning and financing beneficial_use_projects.pdf.

U.S. Fish and Wildlife Service (USFWS). 2014. Conservation Measures to Protect Shorebirds and Piping Plovers on Panama City and Pensacola Beach, FL. Washington, DC: U.S. Fish and Wildlife Service.

Van Gils, J. A., B. Spaans, A. Dekinga, and T. Piersma. 2006. Foraging in a tidally structured environment by red knots (Calidris canutus): ideal but not free. Ecology 87:1189-1202. https://doi.org/10.1890/00129658(2006)87[1189:FIATSE]2.0.CO;2.

Wooldridge, T. H., H. J. Henter, and J. R. Kohn. 2016. Effects of beach replenishment on intertidal invertebrates: a 15-month, eight beach study. Estuarine Coastal and Shelf Science 175:24-33. https://doi.org/10.1016/j.ecss.2016.03.018. 